Stanovsky, D. (2009)"Organizing Marx's Multitude: A Composition on Decomposition." Rethinking

Marxism, vol. 21, no. 2: 216-227, April 2009. (ISSN: 0893-5696) Published by Taylor \& Francis for the Association for Economic and Social Analysis. This is a preprint. Version of record available online at: http://www.informaworld.com/

\title{
Organizing Marx's Multitude: A Composition on Decomposition
}

\section{By Derek Stanovsky}

\begin{abstract}
This article explores a variety of comparisons and contrasts between competing and conflicting notions of the body and of class composition, decomposition, and recomposition within contemporary Marxian theory. It focuses on the recent distinction drawn by Michael Hardt and Antonio Negri between their concept of a nonunified and nonbodily multitude versus more traditional and organic notions of a unified political body emerging through class struggle. Marx's use of the fable of The Belly and the Limbs in volume 1 of Capital provides an alternative conception of the body in which bodily unity is never fixed and where the multitude of Hardt and Negri may also find a home. This reading of Marx is supplemented by discussions of some psychoanalytic and poststructuralist theories of the body from Judith Butler, Gilles Deleuze and Félix Guattari, Rosi Braidotti, and Slavoj Zizek. These theories of the body, along with the fable that appears in Marx, may provide an alternative way of understanding class composition, decomposition, and recomposition in terms of an appropriately rehabilitated conception of the body.
\end{abstract}

\section{ARTICLE}

The image of [man's] body is the principle of every unity he perceives in objects.

- Jacques Lacan, Seminar II, 166, quoted in Judith Butler, Bodies That Matter, 77.

The theory of class composition restates the problem of power in a perspective where recomposition is not that of a unity, but that of a multiplicity of needs, and of liberty.

- Antonio Negri, Marx Beyond Marx, 14.

Earth to earth, ashes to ashes, dust to dust

- Book of Common Prayer.

All that is solid melts into air.

- Karl Marx and Friedrich Engels, The Communist Manifesto, 6. 
Bodies die and decay, so too do societies, classes and social movements. The death of Marxism also has been proclaimed early and often, and each time these obituaries have proved premature. Marxism has continued to take on new incarnations, in much the same way that capital itself perpetually kills off the old forms of production and reinvents itself in startlingly new and ever more ambitious and dangerous ways. When Nietzsche announces the death of God he also writes: "Do we smell nothing as yet of the divine decomposition? Gods, too, decompose. God is dead. God remains dead. And we have killed him" (181). Yet out of deaths and dissolutions grow new life and new ways of living. For Nietzsche the question then becomes, "What next?" What will arise from this "divine decomposition?" What will be made of it? The decomposition of bodies and classes, like the decomposition of gods, gives rise to new possibilities and makes way for their recomposition. The crucial question concerning the reproduction of the body, and the rejuvenation of the social is always, "What next?"

Hardt and Negri's Multitude: War and Democracy in the Age of Empire is, among other things, an exploration of what may come next in the ongoing class struggle. Where their previous work, Empire, traces the emergence of the most recent phases of global capitalism, Multitude elaborates on the newly evolving forms of resistance encountered by Empire. Globalized and distributed geographically on an ever-increasing scale, the fragmentation of the working class has accelerated in recent decades. Soon, even the orders at McDonald's drive-through windows may be taken by workers living in far distant locales and be transmitted by microwave and satellite technologies (McDonald's 2005). "Would you like fries with that?" may become a phrase embedded in the global body of capitalist production, forging a link between workers with no other possibility of daily contact in a way that is both trivial in content and profound in scope. However, these new links also help create the multitude that Hardt and Negri see as a possible basis for global resistance and global democracy. This multitude is the thing they see being regenerated out of the twin decompositions of class and identity politics and arising out of the new, twenty-first century conditions of global capitalism. "Multitude is a class concept" not restricted to waged workers but extending to the "potentially infinite number of classes that comprise contemporary society based not only on economic differences but also on those of race, ethnicity, geography, gender, sexuality, and other factors" (Hardt and Negri 2004, 103). In short, the multitude is comprised "of all those who work under the rule of capital thus potentially as the class of those who refuse the rule of capital" (Hardt and Negri 2004, 106). According to Hardt and Negri, this multitude "refuses the organic unity of the body" and is fundamentally different from past Marxist notions of a unified class in that "the multitude cannot be reduced to a unity and does not submit to the rule of one" $(162,330)$. This claim that bodies possess a unity that the multitude lacks is the focus of this paper.

This paper seeks to provide a reading of Multitude through the lens of some alternative accounts of the body that may help refocus discussions of the concept of the multitude in ways that highlight its connections with the processes of class formation and help distance it from some of its less Marxist and more libertarian interpretations. The analogy between body and class recurs throughout Multitude. Hardt and Negri attempt to carve out a distinction between their own conception of a non-bodily, non-unified 
multitude in opposition to what they see as the more organic unity of the political body shaped by class politics. There are other discussions of the various possible connections and disconnects between the work of Hardt and Negri in Empire and Multitude and other competing versions of Marxian theory (see for example Resnick and Wolff, Dyer-Witherford, and others in Rethinking Marxism, 2001). There are also other works focusing on the intersections of discourse about the body with Marxian and other economic theories (see for example Amariglio and Ruccio, 2001 and Hewitson, 2001). However, the principle aim of this paper is to focus attention on a line of argument internal to Multitude and to argue that the move by Hardt and Negri to distance their own notion of the multitude from previous conceptions of the body is problematic, and that a different approach to the relationship between multitudes and bodies may be both possible and productive. To explore these possibilities, I wish to return once again to Marx.

In Marx, there are certainly moments where the working class is envisioned in terms of a colossal bodily unity. Marx writes that "the collective working organism is a form of existence of capital" and describes workers as all belonging to a single, gigantic working organism that capital has helped usher into existence $(1990,481)$. However, there are also other moments where this presumed unity of the body is itself called into question. In particular, Marx's use of the fable of "The Belly and the Limbs" in Capital, Volume I opens the way to an alternative conception of the body in which any unity that the body may possess is never fixed and where the multitude of Hardt and Negri may itself even find a home. I supplement this reading of Marx with a further discussion of some psychoanalytic and poststructuralist readings of the body, drawing on writings from Judith Butler, Deleuze and Guattari, Rosi Braidotti, Slavoj Zizek and others. The purpose of this is to highlight some of the commonalities between these recent theories of the body, most often associated with discussions of identity politics, and of the multitude envisioned by Hardt and Negri as the next step in the progression of Marxian class politics. These theories of the body, along with the fable that appears in Marx, can serve to illuminate both the necessity and limitations embedded in every totality, especially those of body and class, and draw attention to some of the parallel tensions and promises both within and between current radical social theories in the divide between identity and class politics. Ultimately, the goal is to provide an alternative way of understanding class composition, decomposition and recomposition in terms of an appropriately rehabilitated conception of the body.

In Chapter 14 of Capital, Volume I, in the midst of his discussion of the division of labor, Marx makes an allusion to "the absurd fable of Menenius Agrippa, which presents man as a mere fragment of his own body" (481-2). This fable tells how the parts of the body conspired together in an ill-fated plan to overthrow the tyranny of the stomach by starving it into submission. For Marx, the fable serves as an illustration of the way the individual has become "divided up" by the increasingly specialized work imposed by capital. However, it also serves as an illustration of the way Marx conceives class unity and of the "collective working organism" formed under capitalism in terms of bodily unity $(1990,481)$. 
Marx introduces this curious reference to the story of Menenius Agrippa at the end of a passage cataloging the depredations inflicted on workers by the capitalist division of labor in the process of production. Of the capitalist character of manufacture, Marx writes:

It converts the worker into a crippled monstrosity by furthering his particular skill as in a forcing-house, through the suppression of a whole world of productive drives and inclinations, just as in the states of La Plata they butcher a whole beast for the sake of his hide or his tallow. Not only is the specialized work distributed among the different individuals, but the individual himself is divided up, and transformed into the automatic motor of a detail operation, thus realizing the absurd fable of Menenius Agrippa, which presents man as a mere fragment of his own body. (1990, 481-2)

The fable of Menenius Agrippa to which Marx refers can be found in Livy's History of Rome. It can also be found in Plutarch as well as a wonderful re-telling in Act 1, scene 1 of Shakespeare's Coriolanus. It even re-appears in Charlotte Brontë's 1849 anti-Luddite novel, Shirley. Each of these versions adds something to our reading of Marx, but I will focus on the fable as it appears in Livy.

Livy tells us that on the occasion of a plebeian revolt among the rank and file in the Roman army "a great panic seized the City" certainly at least in the patrician neighborhoods. In an effort to regain control, the Roman Senate sent Menenius Agrippa, a Roman consul of plebian birth, to speak with the soldiers and he is supposed to have won them back over by telling them the following fable of "The Belly and the Limbs." Livy writes:

Back in the days when the various parts of the body did not necessarily all agree with each other, as they do now, but each had its own ideas and its own voice, some of the parts began to think that it was unfair that they should have to worry and toil to provide everything for the belly, while the belly just sat there in their midst with nothing to do but to enjoy the bounty they brought to it. They therefore conspired together, and agreed that the hands would no longer carry food to the mouth, the mouth would no longer open for food, and the jaws and teeth would no longer grind up what they received. The belly growled and tossed about in protest; but the limbs remained steadfast in their angry resolve to starve the belly into submission. Soon though, they began to feel weak. Their fatigue grew worse and worse, until they, the belly and the entire body nearly perished from starvation. Thus, it had become clear that even the seemingly idle belly had its own task to perform, and returned as much as it received; by digesting the food brought to it and returning nourishment to the limbs 
via the blood. (2.32)

Thus, the plebian revolt against their patrician masters is supposed to have been averted with a silver tongue scoring a victory over strong arms. Elsewhere, Marx comments caustically that "Agrippa failed to show that you feed the members of one man by filling the belly of another" $(1969,12)$. For Marx, the fable is simply absurd and the plebeians were duped by Agrippa's specious argument.

Despite its absurdities, what the story does illustrate for Marx is the amazing extent to which capital has actually succeeded in bringing about Agrippa's bizarre vision and has transformed living human bodies into fragments of themselves. The capitalist division of labor divides the person in just such a way, transforming a human being into only that one small part of their total being needed for the specialized job they perform for capital requiring only a fraction of their total capabilities. As Marx writes, the worker becomes "an appendage of that workshop" and of a process of production "which mutilates the worker, turning him into a fragment of himself" $(1990,482)$. Thus, modern maladies such as carpal tunnel syndrome and other repetitive stress injuries are not only symptoms of our times, but symptomatic of the way in which workers have become "divided up" by capital in a quite literal way. Workers become reduced to a strong back, nimble fingers, sharp eye, or welcoming smile of use to capital in some particular process of production at the expense of the rest of their human capacities and potentials. This is true whether the job in question is in the industrial sector of the economy tightening bolts on a Ford Expedition assembly line, in the service sector as a greeter at the front door of a Wal-Mart, or in the academy as a lecturer on Marx. It is this process of the division of labor "which mutilates the worker, turning him into a fragment of himself" that also shapes the worker into a suitable building block of capital itself and "brands the manufacturing worker as the property of capital" $(1990,482)$. Only after being broken down to a single, simple skill can the worker then be assimilated as an "appendage" of that "collective working organism" that is the working class under capitalism and "is a form of the existence of capital" itself (1990, 482 and 481).

This fragmentation of the body of the individual worker by capital is what makes this tale of Agrippa's very different from most other descriptions of the body. In this case, it is not the unity of the body that is being stressed, but its multiplicity. Similarly, Hardt and Negri conceive of the multitude not as a monolithic, single entity, but as something much more fluid, less structured and less cohesive. It is for this reason that they present it in opposition to bodies, both corporeal and political. They argue that the body politic is unified, just like a corporeal body, into a cohesive, single, hierarchal structure. Thus, Hardt and Negri stress that the multitude will "never become a unitary whole divided by hierarchical organs" $(2004,190)$. However, as Marx's fable shows, bodies too may be fluid and lack cohesion, and the organs themselves might resist the imposition of hierarchical control. In this fable, the limbs rebel against the despotic stomach. Perhaps bodies may be imagined that are less monolithic than Hardt and Negri initially assume, and perhaps Marx also tends to conceive of bodies in these more flexible terms. 
However, there is more in Agrippa's fable to hold our attention than the analogy Marx finds with working conditions under capital. It is at this point that some recent psychoanalytic and poststructuralist theories of the body and identity politics might be of help. These theories have tended to focus on the body as itself a site of constant struggle, rather than taking the body as a solid, uncontested ground on which to build foundations. These theories also have some important implications for discussions of class, since bodily formation is now something that might undergo composition, decomposition, and recomposition in much the same way as class formation has previously been conceived within Marxian theory. It is for this reason that I now turn to works by Butler, Deleuze and Guattari, Braidotti, and Zizek for a look at some contemporary theories of the body that share some interesting features both with Agrippa's feuding and conflicting body parts, as well as with Hardt and Negri's nonbodily multitude.

The story of "The Belly and the Limbs" gives a whole new meaning to Freud's oft-quoted pronouncement that "Anatomy is destiny." What sort of destiny is it when it is possible for the various pieces of anatomy to pursue their own separate and competing goals? Here we begin to find room for the discursively produced bodies of Judith Butler, for whom the materiality of bodies is "indissociable from the regulatory norms that govern their materialization and the signification of those material effects" $(1993,2)$. For Butler, bodies must be held together by a set of always provisional and tentative compromises and negotiations, not unlike the negotiations Agrippa seems to suggest are needed to reconcile the competing demands of the belly and the limbs.

Quoting Lacan, Butler notes that: “The image of [man's] body is the principle of every unity he perceives in objects" $(1993,77)$. This is what underlies the progressive and transgressive potential that Butler finds in the performative productions of queer, transgendered, and other alternative bodies. Each such body provides the possibility of a new kind of template for a new kind of unity, and troubles the boundaries and stability of the more typical and more hegemonic unities. Lacan's mirror stage posits bodily unity as something that must be created and mastered. The infant comes to identify with an image of its own bodily unity and totality as reflected back to it by the surrounding world (Lacan 1977, 2). Lacan's insight is that this bodily unity is a fiction that must be produced and maintained and one that is always in danger of disintegrating since the image on which it is based can never coincide with the reality it purports to represent. Butler's insight is to highlight the political possibilities of this necessary mismatch between bodily image and bodily reality and to exploit this gap for its potential to allow the creation of new kinds of images, new kinds of bodies, and also new principles of unity that it may be possible to explore, use, and harness politically. The question then becomes what sort of new totalities, templates, and bodies can we imagine/produce at this particular historical moment for the current politics of class and identity? In this shared quest for new expressions of commonality within the multitude, Hardt and Negri's project may be seen to possess certain similarities with Butler, and in fact they invoke Butler in their discussion of the performative production of the common by the multitude (199-200). It is this performative and active process of creation of both the body and class that connects the two. 
Menenius Agrippa's fable of "The Belly and the Limbs" may also provide a space for Gilles Deleuze and Felix Guattari's infamous "bodies-without-organs" which is, after all, only an inversion of Agrippa's warring organs-without-bodies. The "body-withoutorgans," described by Deleuze and Guattari and extracted from the autobiographical account of Judge Schreber's paranoia, is the surface where organs are "miraculated" and so appear as agents of a bodily unity and totality which is always already absent in much the way that capital itself appears to miraculously be the source of the production of surplus-value where money magically seems to create more money so that the rich continually get richer without lifting a finger (Deleuze and Guattari 1983, 10-11). Judge Schreber describes his own unruly body and experiences attacks on his organs ranging from "the removal by miracles of single hairs from my beard" and the removal and recreation of his heart, lungs, stomach, spinal cord to his "skull being partly pulverized" and then "restored again" (Schreber 2000,147). It is passages such as these that lead Deleuze and Guattari to describe the body-without-organs as swarming with organs "as a lion's mane swarms with fleas" $(1983,16)$. For them, the body-without-organs "is opposed not to the organs but to that organization of the organs called the organism" $(1987,158)$.

A similar contrast with any easy notion of bodily unity can be found in the rebellious organs imagined by Agrippa and Marx. In this case, the autonomous organs-withoutbodies attack each other as independent free agents without any regard for an underlying unity, bodily or otherwise. In a footnote to his discussion of Menenius Agrippa, Marx adds a charming, if inaccurate, example from nineteenth century zoology writing:

In corals, each individual is, in fact, the stomach of the whole group; but it supplies the group with nourishment instead of extracting it, like the Roman patrician. (1990, n41, 482)

Marx's invocation of the alternative body architecture of corals is suggestive of the more complex bodily metaphors of roots, radicals, and rhizomes used by Deleuze and Guattari. This might also encourage us to consider still other arrangements of bodies such as slime molds or viruses, each of which might provide us with a different way of understanding how bodily unities are produced and maintained and how the organization of organs into organisms is accomplished (1987, 3 ff.). These alternative templates for producing and organizing multitudes may find application equally well in both the cases of body and of class. For instance, Hardt and Negri write:

One of the most surprising elements of the events in Seattle in November 1999 and in each of the major such events since then is that groups we had previously assumed to have different and even contradictory interests managed to act in common - environmentalists with trade unionists, anarchists with church groups, gays and lesbians with those protesting the prison-industrial complex. The groups are not unified under any single authority but rather relate to each other in 
Here we encounter an alternative group architecture easily as exotic as the alternative bodily architectures discussed above, and one that does not fit into any simple notion of hierarchal organization. The cooperation of many diverse groups in ways that are so complex and creative is something that has been achieved without the benefit of any central planning or control.

Rosi Braidotti has also explored this notion of organs-without-bodies in the context of the intersection of gender and technology. Braidotti writes that, "the whole discourse of the biosciences takes the organism as its object, and it therefore takes the body as a mosaic of detachable pieces" $(1994,47)$. This mosaic of detachable pieces produced by science and technology corresponds to the mosaic of detachable organs imaginatively produced by Agrippa in his fable. For Braidotti, these more recent and tangible technological interventions, like those of in vitro fertilization and contraceptives, have resulted in the dissociation of organs from their biological functions and the creation of technologies that now make possible such things as sex without reproduction and reproduction without sex. Slavoj Zizek includes the vibrator on this list of gendered technological devices as yet another kind of technologically produced "organ without a body" which also serves to detach sex from reproduction (2004, n31, 174). Although Zizek seems to have completely repressed any memory of Braidotti's earlier writings on organs-without-bodies in his 2004 book, Organs Without Bodies, his work also questions the presumed boundaries, integrity, and unities of the body in some interestingly provocative ways.

Writing on the political potentials of these organs-without-bodies, Zizek speculates on an example from popular culture with a discussion of David Fincher's 1999 film, Fight Club, and the infamous scene where Ed Norton beats himself up using his own strangely "autonomized hand" in an assault more direct and immediate than the bodily siege imagined by Agrippa (2004, 172). Zizek writes,

the self-beating begins with the hero's hand acquiring a life of its own, escaping the hero's control - in short, turning into a partial object, or, to put it in Deleuze's terms, into an organ without a body (the obverse of the body without an organ). (2004, 173)

This turning upside down of agency and subjectivity, where suddenly it is the hand that acts and not the person, provides Zizek with a perverse, and perversely subversive, model of revolutionary agency, action and subjectivity. Marx's much earlier invocation of Agrippa's fable of "The Belly and the Limbs" provides an odd parallel to Fincher's Fight Club and also serves to unsettle and unhinge the presumed unity of the body by raising the specter of "autonomized" organs acting on their own and even acting against the body proper. These moments of autonomy, even within the supposed hierarchy of a body, make it possible for these imagined alternative accounts of the body to be open to some of the same political concerns and questions that animate contemporary debates 
on class and on multitudes. For instance, there are the unpremeditated links between otherwise autonomous struggles that have nonetheless also helped "form a cycle of struggles ... across the globe" linking such disparate elements as the FMLN in El Salvador with Justice for Janitors in Los Angeles, or the WTO protests with mobilizations against the war in Iraq (Hardt and Negri 2004, 214-5). The linking together of these autonomous struggles in unforeseen and unforeseeable combinations have produced some surprising, and surprisingly powerful, results in the struggle against capital. In this regard, one might think of the various splits, factions, and tendencies within Marxism, and the Left generally, where parts have taken autonomous actions of their own against more established collective wholes. There have also been the recent defections of various unions from the umbrella organization of the AFL-CIO where the rebellion of parts against wholes again becomes readily visible. These splits and divisions, though, have often resulted in new combinations that have resulted in unforeseen forms of resistance and action. For example, the shattering of indigenous communities by the war in Guatemala resulted in the importation of Guatemalans to Morganton, NC to work in poultry processing plants and brought about the unintended consequence of re-energizing union activism in the deep South (Fink 2003).

In Marxist terms, one of the interesting effects of the story told by Menenius Agrippa is the way it provides both a model for class unity at the same time as it undermines the very possibility of that model. Class unity is often portrayed by reference to bodily metaphors. One of the most commonly used is that of five fingers united together into a fist. Stretching back through Hobbes' body of the sovereign and the mythic severed halves of the original lover's body in Plato's Symposium, the body has provided an almost irresistibly attractive metaphor for political and social unities of various types. Marx himself describes class composition in terms of a single "collective working organism" and later Marxist writings are replete with images of a working class unified into a single, usually male and often hammer wielding, body $(1990,481)$.

However, Agrippa's tale raises disturbing doubts about not only class unity, but also about the bodily unity on which it is to be patterned. Class decomposition and recomposition are well-understood corollaries of class composition. The working class fractures around a multitude of divisions between industries, across national borders, and along lines of gender, race, religion, language, ethnicity, sexual orientation, etc. The working class also re-forms and re-composes itself across and around these same divisions, healing the schisms and growing larger and stronger. Bodies too decompose. This sometimes happens in sudden, violent, and spectacular ways as when limbs are lost in wars, traffic accidents, or to flesh-eating diseases like gangrene, leprosy, or necrotizing fasciitis. It also happens slowly and inevitably through the mundane actions of time, age, death, and decay. These are commonplace events. What is more startling is the fact that bodily composition and recomposition might be real possibilities. These compositions and recompositions range from the symbolic creations of the Lacanian mirror stage, to the aesthetic body modifications of tattoos and piercings, to the more ambitious technological interventions of organ transplants, plastic surgeries, prosthetic devices, cloning, and even cryogenics when all else fails. This makes the analogy between body and class much closer. It also may make the analogy less useful. Bodies 
may lack exactly the sort of unity and coherence that was being sought and that was the reason for their comparison to class in the first place.

By the end of Multitude, Hardt and Negri begin to suspect that their earlier division between unified, coherent bodies and the swarms of their multitude is perhaps an untenable one. They write:

Perhaps we were wrong earlier ... to say that the multitude betrays the traditional analogy between the human body and the social body, that the multitude is not a body - but, if so, we were wrong for the right reason. If the analogy holds, in other words, it is because the human body is itself a multitude organized on the plane of immanence. (2004, 337)

Thus, the teeming neurons of the brain, rather than forming "a centralized model of intelligence with a unitary agent" may instead be understood as forming a network, "a swarm, a multitude that acts in concert" $(2004,337)$. This same insight can be gleaned from psychoanalysis no less than from contemporary neurobiology. Psychoanalysis insists on the always tentative, provisional, and partial nature of the conscious ego. The deep and constitutive divisions that underlie and make possible the emergence of a subjectivity that is in fundamental conflict with its own unconscious drives and desires is something that analysis uncovers time and time again. Coherence is something produced and maintained with great effort and often at great cost. It is not something that already exists from the outset.

On the other hand, bodies do often manage to achieve a very convincing and persistent semblance of unity and cohesion. This might make comparisons between body and class even more productive, although, it will certainly complicate them greatly. On this view, class politics and identity politics share a common problem. How can a unity be forged from disparate pieces that will be able to bear the weight of a collective politics without doing violence to its constitutive parts? In class politics, unity is sought amid the many and obvious difficulties of building class unity. In the case of identity politics, unity is often sought in the less obvious, but no less problematic, terrain of the body. Recognizing this shared problem may also point to some useful strategies for negotiating the apparent divide between class and identity politics.

Slavoj Zizek writes: "The only solution to this deadlock seems to be to accept it as such - to accept that we are condemned to the unending struggle between particular elements to stand in for the impossible totality" $(2000,92-3)$. The title of his essay is "Class Struggle or Postmodernism? Yes, Please!" a play on an old Marx Brothers routine where Groucho is asked the question "Tea or coffee?" and refuses the choice with the answer of "Yes, please!" The solution Zizek offers to this theoretical bind is the same choice of refusing to choose. He writes, 
one should answer in the same way the false alternative today's critical theory seems to impose on us: either 'class struggle' (the outdated problematic of class antagonism, commodity production, etc.) or 'postmodernism' (the new world of dispersed multiple identities, of radical contingency, of an irreducible ludic plurality of struggles). Here, at least, we can have our cake and eat it ... (2000, 90)

For instance, there is the building and strengthening of the "collective working organism" that is the task of class composition. This task seeks the liberation of workers within their roles as workers and so strives to raise wages, improve working conditions, and shorten the working day. These are important and necessary struggles. However, there is also the simultaneous goal of the destruction of this "collective working organism," the abolition of the working class, and the abolition of capitalism. This is also an important and necessary struggle, but one which is not always clearly compatible with the first set of struggles, and which, as Zizek writes, "effectively provides the horizon" against which these other struggles take place $(2000,98)$. What Zizek hopes to refuse is the choice where these two kinds of struggle are offered as a strict either/or - where the impossibility of perfecting a post-revolutionary society is held up as reason to pursue only smaller, local issues; or, conversely, the goal of the overthrow of capital is used to hold hostage a vast array of pressing local struggles. Zizek writes,

this justified rejection of the fullness of post-revolutionary Society does not justify the conclusion that we have to renounce any project of a global transformation, and limit ourselves to partial problems to be solved: the jump from a critique of the 'metaphysics of presence' to anti-utopian 'reformist' gradualist politics is an illegitimate short circuit. $(2000,101)$

In short, to say that total revolution is impossible is not the same as saying that we must settle for only partial revolutions. This, of course, works both ways. A successful class revolution that leaves intact sexism, racism, and heterosexual privilege is also only a partial revolution in need of still more radical transformation. Class formation too is staged within the confines of the existing structures of gender, racial, and sexual identities and can either work within those boundaries or work to transgress those boundaries, and both projects may often happen simultaneously. There are other permutations that can be considered, but in each case there is no ready-made totality that can safely serve as the horizon against which every other struggle must take place. Rethinking the ways the body has figured into theories of class highlights this always provisional nature of unity and totality and may provide some possible strategies for negotiating and renegotiating this recurring divide. Another version of this argument can be gleaned from the work of the combined authorial body of J.K. Gibson-Graham who argue that capital itself also never succeeds in attaining a "monolithic and homogenous" unity and that this "fantasy of wholeness" that capital often feigns instead "operates to obscure diversity and disunity in the economy and society alike" (260). Another way of 
stating this might be to say that capital works to hide and obscure the multitudes that comprise it.

Hardt and Negri echo the call for the refusal of a choice based on a false dichotomy. They write:

The concept of multitude, then, is meant in one respect to demonstrate that a theory of economic class need not choose between unity and plurality. A multitude is an irreducible multiplicity; the singular social differences that constitute the multitude must always be expressed and can never be flattened into sameness, unity, identity, or indifference. $(2004,105)$

However, the unities of bodies may be more multitudinous than Hardt and Negri originally allow. Even in Marx, the specter of a body at odds with itself that is hinted at in Agrippa's fable raises the suspicion that bodies may also be multitudes. Thus, a politics of class that envisions class unity as modeled on bodily unity may not necessarily fall victim immediately to the rigidities of fixed and untenable hierarchies and organizations. Multitudes are not so easily contained, either in theory or practice, and may find a way to squeeze through the cracks.

\section{Bibliography}

Amariglio, J and D. Ruccio. 2001. "From Unity to Dispersion: The Body in Modern Economic Theory." In Postmodernism, Economics and Knowledge. Eds. Stephen Cullenberg, Jack

Amariglio and David F. Ruccio, pp. 143-165. New York: Routledge.

Braidotti, R. 1994. Nomadic Subjects: Embodiment and Sexual Difference in Contemporary Feminist Theory. New York: Columbia University Press.

Butler, J. 1993. Bodies that Matter: On the Discursive Limits of "Sex." New York: Routledge.

Deleuze, G., and F. Guattari. 1983. Anti-Oedipus: Capitalism and Schizophrenia. Trans. Robert Hurley, Mark Seem, and Helen R. Lane. Minneapolis: University of Minnesota Press.

Dyer-Witheford, N. 2001. "Empire, Immaterial Labor, the New Combinations, and the Global Worker." Rethinking Marxism 13 (3/4): 70-80.

1987. A Thousand Plateaus: Capitalism and Schizophrenia. Trans. Brian Massumi. Minneapolis: University of Minnesota Press. 
Fink, L. The Maya of Morganton: Work and Community in the Nuevo New South. Chapel Hill: University of North Carolina Press.

Gibson-Graham, J. K. 1996. The End of Capitalism (as we knew it). Oxford: Blackwell Publishers.

Hardt, M., and A. Negri. 2004. Multitude: War and Democracy in the Age of Empire. New York: Penguin Press.

Hewitson, G. 2001. "The Disavowal of the Sexed Body in Neoclassical Economics." In Postmodernism, Economics and Knowledge. Eds. Stephen Cullenberg, Jack Amariglio and

David F. Ruccio, pp. 221-245. New York: Routledge.

Lacan, J. 1977. Écrits: A Selection. New York: W. W. Norton.

Livy. 1967. The Loeb Classical Library, Vol. 1. Trans. B. O. Foster. Cambridge: Harvard University Press.

Marx, K. Value, Price and Profit. 1969. New York: International Publishers.

—. Capital, Volume I. 1990. Trans. Ben Fowkes. New York: Penguin.

Marx, K. and F. Engels. 1992. The Communist Manifesto. Oxford: Oxford University Press.

"McDonald's may outsource drive-thru order-taking." USA Today. 3 March 2005, (6 October 2005). <http://www.usatoday.com/money/industries/food/2005-03-10mcd_x.htm>.

Negri, A. 1991. Marx Beyond Marx. New York: Autonomedia.

Nietzsche, F. 1974. The Gay Science. Trans. Walter Kaufmann. New York: Vintage.

Resnick, S. and R. Wolff. 2001. "Empire and Class Analysis." Rethinking Marxism 13 (3/4): 61-69.

Schreber, D. 2000. Memoirs of My Nervous Illness. Trans. Ida Macalpine and Richard A. Hunter. New York: New York Review Books.

Zizek, S. 2000. "Class Struggle or Postmodernism? Yes, please!" In Contingency, Hegemony, Universality: Contemporary Dialogues on the Left. Judith Butler, Ernesto Laclau, and Slavoj

Zizek, pp. 90-135. London: Verso.

- 2004. Organs without Bodies: On Deleuze and Consequences. New York: Routledge. 